\title{
Assessment of the Scots pine (Pinus sylvestris L.) crowns density based on multispectral images obtained by unmanned aerial vehicle
}

\author{
Krzysztof Stereńczak, Krzysztof Będkowski
}

Department of Forest Management, Geomatics and Economics

Warsaw University of Life Sciences - SGGW

Nowoursynowska 159, 02-766 Warsaw, Poland

e-mail: k.sterenczak@ibles.waw.pl

\begin{abstract}
This paper presents the use of non-metric multispectral digital images analysis acquired by cameras carried by unmanned flying vehicles (UAVs) to assess the density of crowns in Scots pine stands. Images were acquired in October 2011. During the field data acquisition, 272 pine trees were inventoried and classified to 10 classes based on the crown density. These results were compared with the average pixel brightness in four spectral channels B, G, R and IR, collected in three variants - the whole crown, dense part of the crown (the so-called rejection of "outlier" branches) and the central part of the crown with 0.63 m radius. Studies have shown that brightness of images of tree crowns belonging to different classes of density varies insignificantly. This especially concerns the class of trees with a very high degree of defoliation (70-100\%) and dead trees. The degree of stabilization can be observed in class 5 , which means that a further increase in crown density does not increase the spectral reflectance. Analyzes revealed strong similarity between crowns variants: spectral images obtained for the whole or a part of the crown do not differ from each other. Ultimately, it is difficult to determine which variant is the best for the further classification procedure.
\end{abstract}

Key words: aerial imagery, training fields, spatial resolution, spectral characteristics

\section{Introduction}

Damages of forests are usually caused by various biotic or abiotic factors, such as: gradation of insects, diseases caused by fungi, industrial pollutants, changes in groundwater levels, fires, hurricanes, floods, snow, etc. These factors reduce the growth rate of trees, affect quality of timber, and sometimes lead to death of trees (Wastenson et al. 1987; Wójcik \& Czarnecka 2001). Their negative impact on the effects of human activity in forests is indisputable.

It happens, however, that the short term loss of leaves do not affect the status and growth of trees (Stone \& Haywood 2006). One should therefore be very cautious about the fact that at the time trees has reduced their suit of leaves. Needle suit condition should always be considered in a broader perspective, not just itself alone.

Symptoms of trees damage are usually: loss of foliage and chlorosis, i.e.: quantitative and qualitative changes. Frequently, it is necessary to deal simultaneously with these two processes, and observed state crown is effect of both. Variations in health are reflected in changes in the ability to reflect electromagnetic radiation. In order to assess the state of vegetation health, an electromagnetic wave reflectance value must be registered in the range from about 350 to $1200 \mathrm{~nm}$, corresponding to the range of spectrum of the blue, green, red and near infrared (Greer et al. 1990; Jaszczak 2000; Stone \& Haywood 2006). This spectrum can be recorded using aerial images (photograph- 
ic films, digital cameras) in natural colors (NC) and color infrared (CIR).

The dramatic deterioration in the forests health has become a phenomenon observed in Europe, especially in the 70 and 80 of the 20 . century. This is due to natural factors: adverse weather conditions (droughts and hurricanes), gradations of insects, as well as air pollution, mainly by sulfur dioxide $\mathrm{SO}_{2}$ emissions from industrial sources. The scale of the phenomenon was so large, that it seriously affected forest management. It is necessary to know that the extent of the damage data was collected as a part of the periodic inventory of the forest. Since the beginning, remote sensing data were included both from airborne and satellite level. During this time, specific methods and inventory technologies of damage inventories to the main forest species: spruce, fir, pine, beech, oak, birch and others, have been developed (Bychawski et al. 1984; PPGiK 1984; Heidingsfeld 1993; Zawiła-Niedzwiecki \& Fedorowicz-Jackowski 1993; AFL 2003). The primary material of image registration was reversible Kodak film 2443 (Pollanschütz 1968, 1981; Hildebrand \& Gross 1992). An interpretative key was describing photographic material quantitative and qualitative changes within the crown, including the variability of natural forms and crown foliage of a given species (Zirm et al. 1985a; Fibich et al. 1986a; Kenneweg 1989). Visual image interpretation was completed and was supplemented by digital analysis of scanned aerial photographs (Schneider \& Plank 1981; Zirm et al. 1986b; Wastenson et al. 1987, Pinz 1988) or material derived directly from aerial or satellite scanners (Pillmann \& Zobl 1988; Schneider 1989).

Ground-based methods for assessing the health of trees used in Poland take into account the defoliation, tree vitality, which is the result of defoliation and the developmental stage of the crown, and the detailed characteristics of foliage - color of needles or leaves, the occurrence of offshoots and dry peaks. For the assessment of defoliation and tree crowns conditions, manuals and interpretation keys were prepared, containing drawings and sketches (Borecki \& Keczyński 1992). Scots pine, as the most important species in Poland, went through a number of studies on the crown condition assessment, which, however, relate mostly to terrestrial methods of inventory (Borecki 1991; Becker 1993; Dmyterko 1996; Wojcik 2000; Jaszczak 2000, 2001; Wojcik \& Czarnecka 2001; Socha \& Ochał 2002). From the airborne level, pine damage were evaluated, inter alia, by Miścicki 1981 (CIR images) and Mozgawa et al. 1994 (video images).

With the development of Unmanned Aerial Vehicles, the possibility of obtaining aerial images, both in the natural colors and IR channels, greatly increased. The usefulness of forestry images obtained by means of the UAV was confirmed experimentally (Rango \& Laliberte 2010; Suzuki et al. 2010). Zmarz et al. (2012) examined the health status of a Norway spruce (Picea abies (Karst.) L.) stand. Będkowski and Stereńczak (2012) made an effort to distinguish the images for alien forests species, such as red oak (Quercus rubra L.). This paper presents investigation of possibility of using non-metric digital multispectral images obtained by cameras carried by unmanned aerial vehicles (UAVs) to assess canopy density in pine stands (Stereńczak \& Będkowski 2012).

Following factors characterize images used in presented work:

- Sensor recording images - two modified non-metric Sigma DP2 digital cameras, able to record the following range of radiation: blue $(\mathrm{B}$ - maximum camera sensitivity in $500 \mathrm{~nm})$, green $(\mathrm{G}$ - maximum camera sensitivity in $570 \mathrm{~nm}$ ), red ( $\mathrm{R}$ - maximum camera sensitivity in $640 \mathrm{~nm}$ ) and infrared (IR - sensitivity was not determined).

- Data of image acquisition - images were taken at the end of the growing season (27 October 2011).

- Weather and lighting conditions - diffuse illumination resulting from the slight cloudiness dominated during the shooting. The resulting images are termed as shadowless.

- Used UAV - UAV was able to carry out two non-metric Sigma DP2 digital cameras: one able to record RGB and second - IR range of the electromagnetic reflectance.

The proposed solution is, from an economic and operational point of view, very competitive as compared to traditional airborne photogrammetry. Competitiveness is manifested, among others, by the possibility of taking pictures on cloudy days, so it is possible to flight almost in every weather condition.

Most important limiting factors are, however: strong wind (UAV has a relatively weak design and low weight) and low temperatures, resulting in decrease in battery capacity - the source of energy for UAV engine.

\section{Materials and methodology}

\section{Test site}

The study was conducted in Gluchow Forest, a part of the Forest Experimental Station in Rogow, belonging to Warsaw University of Life Sciences - SGGW. Gluchow covers an area of 967.39 hectares, 905.42 hectares of which is forested. It is located in the municipality of Gluchow, in the district of Skierniewice in Central Poland (51 $45^{\circ}$ ' 19 ' $\mathrm{N}$, 2006'30' E).

\section{Unman Aerial Vehicle}

The UAV AVI-1 (Taxus SI 2010; Zmarz 2011) was designed specifically for performing photogrammetric flights. It is 


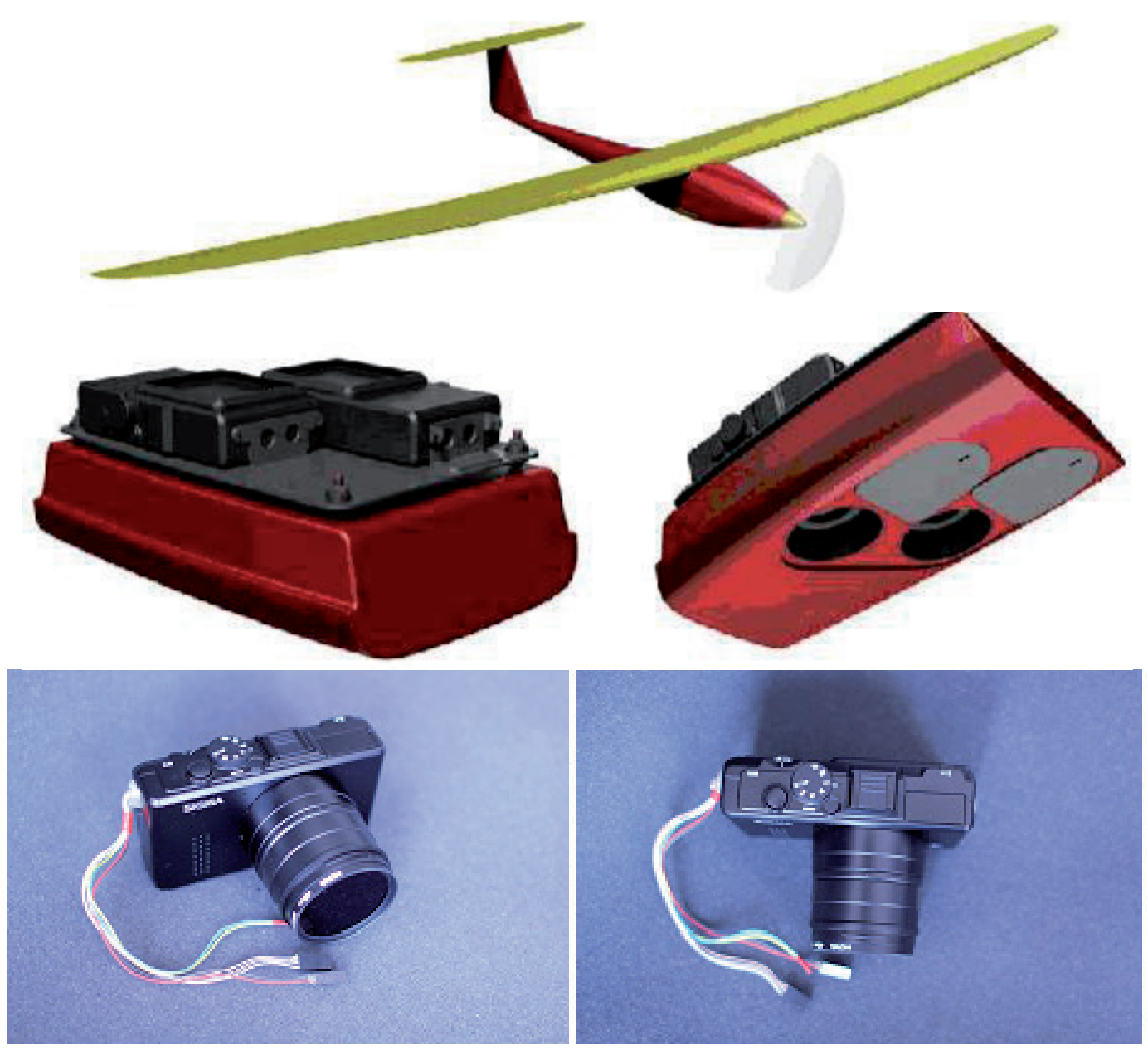

Figure 1. Unmanned aerial vehicle AVI-1, the installation of two Sigma DP2 cameras - visible wires are used to connect the controller (Source: Taxus 2010, Zmarz 2011)

a composite structure with electric engine and a wingspan of $3.5 \mathrm{~m}$ (Fig. 1). The vehicle is controlled by the autopilot. Within hours of the flight it is able to flight over the area of about 3 to $4 \mathrm{~km}^{2}$. Capacity of AVI-1 allows to mount one standard digital camera or two compact cameras.

During the project, flights were carried out under light cloud cover. The following flight parameters were achieved:

- forward and side overlap within $65 \div 70 \%$,

- ground sampling density (GSD) $-14 \mathrm{~cm}$,

- flight AGL altitude - 350 meters,

- the distance between trajectories - 55 to 60 meters,

- flight speed - $17 \mathrm{~ms}^{-1}$,

- shooting interval $-5.4 \mathrm{~s}$,

- coverage -45 hectares of forest area,

- radiometric resolution -8 bit.

\section{Non-metric multispectral digital images}

Pictures were taken in four spectral channels: blue (B), green $(G)$, red $(R)$ and near infrared (NIR), ranging from 0.4 to about 1.1 micrometers wavelength of electromagnetic radiation. They were processed automatically to form an ortho-mosaic. The ortho-mosaic is an image covering large area, resulting from a combination of a few to several hundred fragments of original images, without geometric distortions. Geometric distortions are caused by the geometric representation of spatial objects with central projection and camera optical axis deviation at the time of shooting.

The flight over the Glochow Forest covered forest management units number: 190-192, 197-199, and 206, and ground sample plots covered 4 units (Table 1). The flight covered mostly one layer stands, with, sometimes, quite strong undergrowth. 
Table 1. Description of stands covered by photogrammetric flight

\begin{tabular}{|c|c|c|c|c|c|}
\hline Area code & Unit number & $\begin{array}{c}\text { Dominant tree } \\
\text { type }\end{array}$ & $\begin{array}{c}\text { Age } \\
\text { [years] }\end{array}$ & Stocking & $\begin{array}{c}\text { Average height } \\
\text { [m] }\end{array}$ \\
\hline $190-\mathrm{c}-00$ & 190 & Pine & 65 & 0.8 & 21 \\
\hline $197-\mathrm{c}-00$ & 197 & Pine & 54 & 0.8 & 17 \\
\hline $198-\mathrm{a}-00$ & 198 & Oak & 76 & 0.8 & 21 \\
\hline $198-\mathrm{b}-00$ & 198 & Pine & 64 & 0.7 & 22 \\
\hline
\end{tabular}

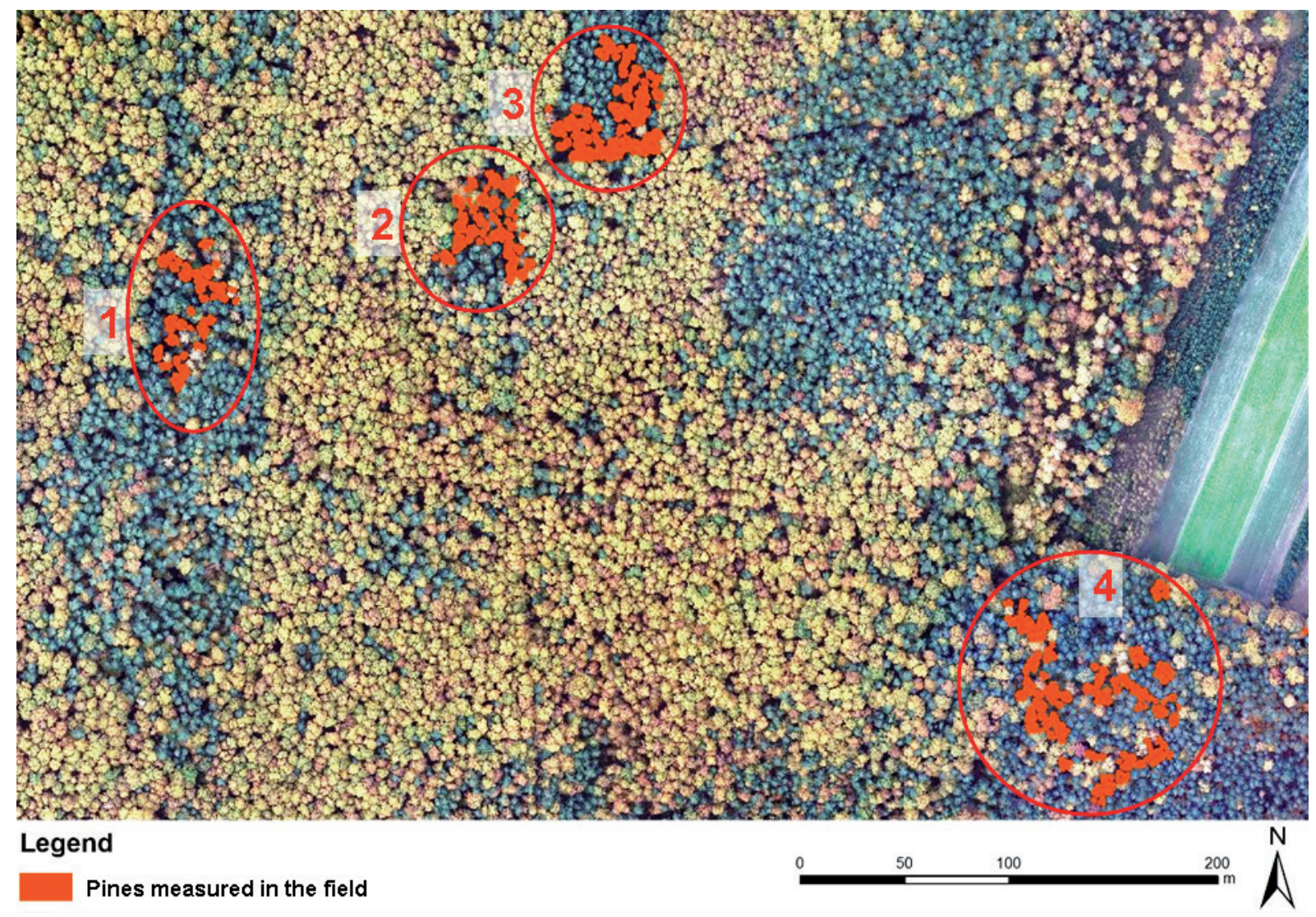

Figure 2. Distribution of four Scot pine samples plots (four groups), inventoried in the field, with the background of ortho-mosaic (composition in natural colors, RGB)

\section{Sample plots}

Four ground sample plots were established in the area covered by the ortho-mosaic (Fig. 2, Tab. 1). The arrangement of sample plots guaranteed to consider the possible spectral differences between successive images (or ortho-mosaic fragments) and natural differences between stands.

During field work the visual determination of the degree of Scots pine crowns density was carried out. It was expressed by a number ranging from 1 to 10 (Fig. 3). Class 1 means that $10 \%$ of potential needles amount covers branches in crown and 10 means that crown has a maximum needle cover. Crown density was defined by the amount of foliage on the crown. Generally, visual comparison of each tree to the 'ideal' or 'perfect' (class 10) tree was carried out. "Ideal' or 'perfect' tree is a tree with a totally opaque crown. Comparisons were made with reference to a tree with the maximum amount of foliage under the conditions obtaining wildly - 'absolute reduction in crown density' (ARCD) or locally - 'local reduction in crown density' (LRCD) (Redfern \& Boswell 2004). In our case we used the LRCD method. The assessment related to needles, not branches. The used division into 10 classes re- 


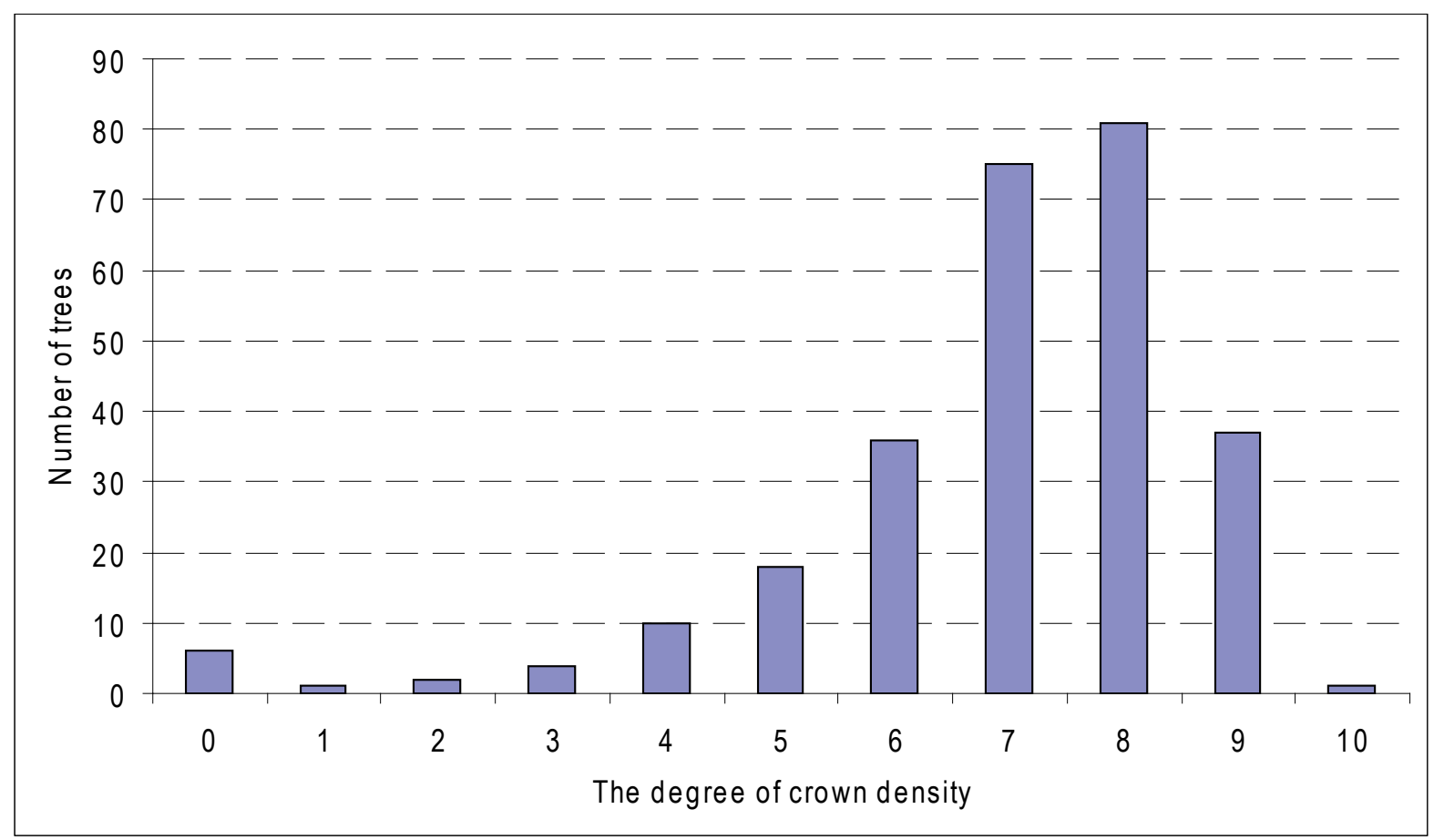

Figure 3. The distribution of the surveyed trees in ten degrees of crowns density

fers to the procedure used in forest practice, where accuracy of assessing forest defoliation is about 10\% (Dmyterko 1996). In our case, the degree of 10 received crowns, which had the most complete suite of needles; other trees were compared to the best and received a lower value. Individual branches, firmly pulling away from the compact part of the crown, were not taken into account. No sign of discoloration of needles was noticed on the trees.

\section{Analysis of the pine crowns spectral characteristics}

In the first place, materials obtained in the field were processed and pine crown digitalization based on ortho-mosaics was carried out (Fig. 4). The digitalization was made in three crown range variants:

- Variant 1 - the whole crown outline, even with single "offstanding" branches,

- Variant 2 - the compact crown, without a single "offstanding" branches. This part of the crown should not let light reflected from vegetation located below to go thought.

- Variant 3 - the central part of the crowns - circles with a radius of $0.63 \mathrm{~m}$ - buffer formed around the centroids exported from whole crowns. Beam size was chosen so that the surface area of the circle corresponds to the smallest digitized pine crown $\left(1.253 \mathrm{~m}^{2}\right)$. Because of creating buffers in the raster model datasets, the buffered surface has 57 pixels and its shape differs from a perfect circle (Fig. 4).
Spectral analysis of tree crowns for different degrees of density was carried in Idrisi Taiga (2009) in four spectral channels (B, G, R, and IR). Amount of reflection was recorded in pixel brightness as dimensionless number, in the range 0 to 255 . Image brightness, expressing the relative amount of the radiation registered by sensor, where 0 means no radiation, and 255 means the maximum recorded radiation.

The following methodology was adopted for analyzes:

- Based on the field observations, digitized canopies were divided into 10 classes of crown density, from 0 to 10 ,

- From each image channel, pixels belonging to the crown (3 variants) were analyzed with respect to the density class and the average pixel brightness was calculated,

- Statistical analyzes of spectral characteristics (in four channels) in different variants of crown size and density classes were carried out.

\section{Results}

The mean brightness of crowns (or their parts) is shown in Fig. 5, 6, 7 and 8. Analyses were performed using the original images, without contrast pre-processing. The main observation is that trends for all variants are very similar. In all cases, the channel 4 has the lowest brightness value. It is due to the fact that the recording matrix in the infra- 

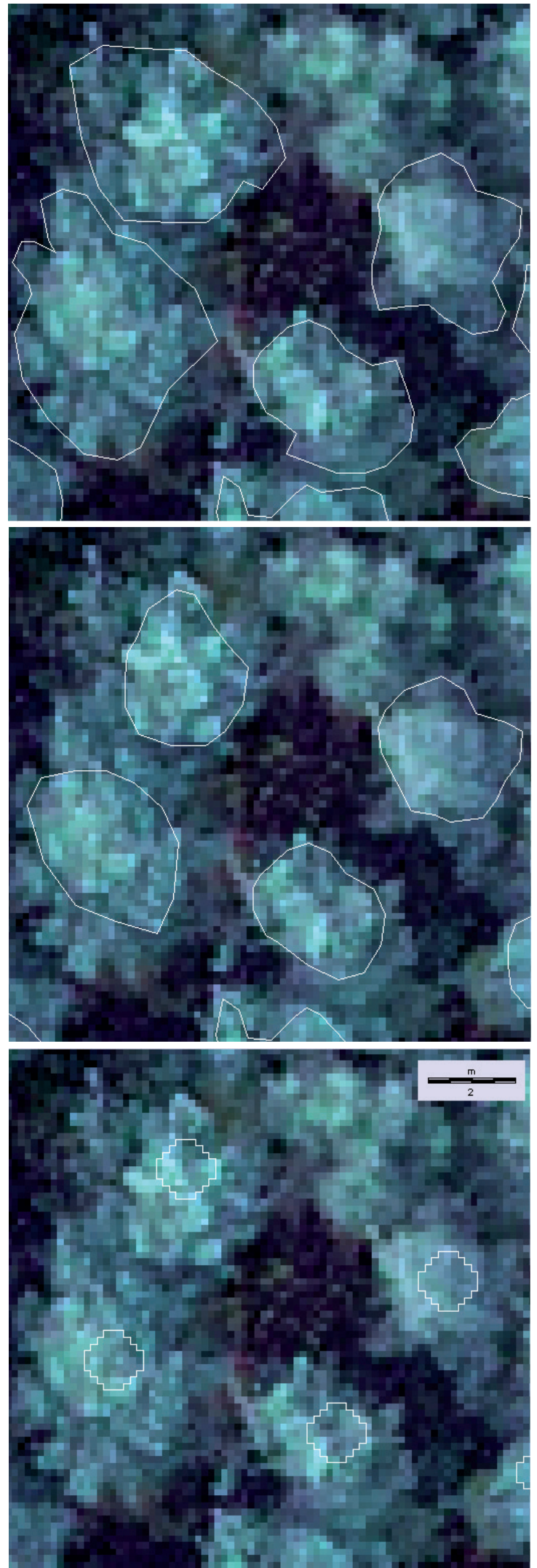

Figure 4. Digitalization of pine crowns range (top - the whole crown (Variant 1), middle - the compact crown (Variant 2), bottom - central part of the crowns (Variant 3)) red spectrum has lower range of sensitivity than the other ones. Values for the channel 4 show different brightness values in different degrees of crown density: lower grades $(1 \div 4)$ differ significantly $(p=0.000)$ from the other levels of brightness $(5 \div 10)$. It has to be noticed that this trend is very clear, but taken from relatively small number of trees.

With regard to the brightness of crown pixels, the aim of the analysis was to determine whether there is a statistically significant difference between the information stored in different spectral channels, in the context of distinguishing between tree crowns densities. Stems of dead trees were not included in this analysis, mainly because they are easily distinguishable from live trees.

The paired t-test results performed for mean pixel brightness values (Table 2) brought the following results (significance level 0.05):

- for channel 1 (blue) - all variants differed significantly from each other $(\mathrm{p}=0.00)$,

- for channel 2 (green) - there is no significant difference between variants 2 and 3 ( $\mathrm{p}=0.139)$ (Table 2 , in bold). For other variants of analysis exist significant difference other $(\mathrm{p}=0.00)$,

- for channel 3 (red) - there is no significant difference between variants 2 and $3(\mathrm{p}=0.160)$ (table 2 , in bold). For other variants of analysis exist significant difference other $(p=0.00)$,

- for channel 4 (infrared) - all variants differed significantly from each other $(\mathrm{p}=0.00)$.

Table 2. Mean pixel brightness values in 4 spectral channels and 3 variants of crown extend definitions

\begin{tabular}{|c|c|c|c|c|}
\hline Variant & $\mathrm{B}$ & $\mathrm{G}$ & $\mathrm{R}$ & $\mathrm{IR}$ \\
\hline 1 & 111.84 & 121.74 & 107.98 & 61.17 \\
\hline 2 & 116.16 & 127.9 & 112.39 & 64.82 \\
\hline 3 & 118.87 & 130.03 & 114.27 & 69.72 \\
\hline
\end{tabular}




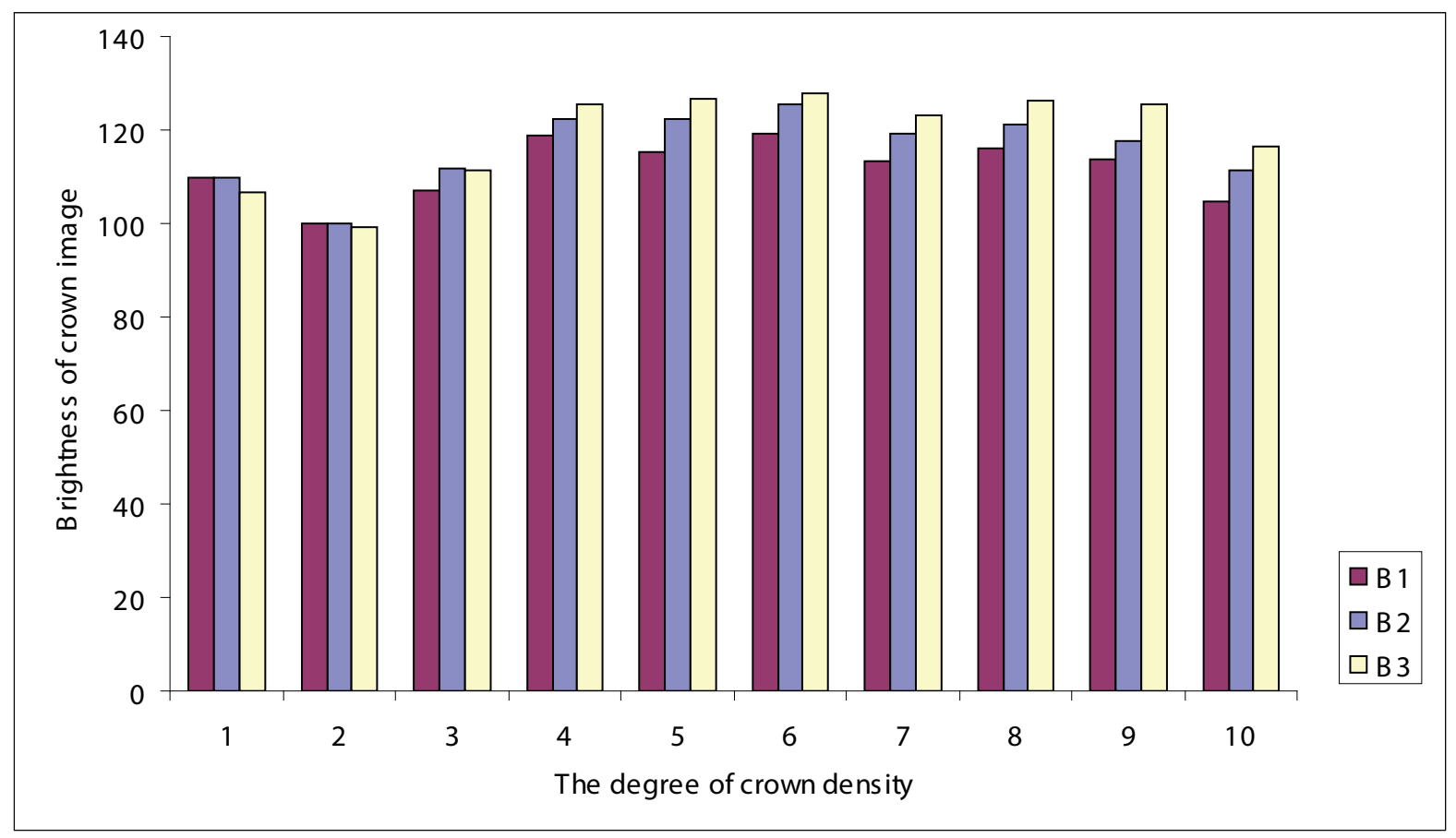

Figure 5. he brightness of crowns in blue channel UAV according to degrees of density crowns for 3 variants $(1,2$ and 3$)$

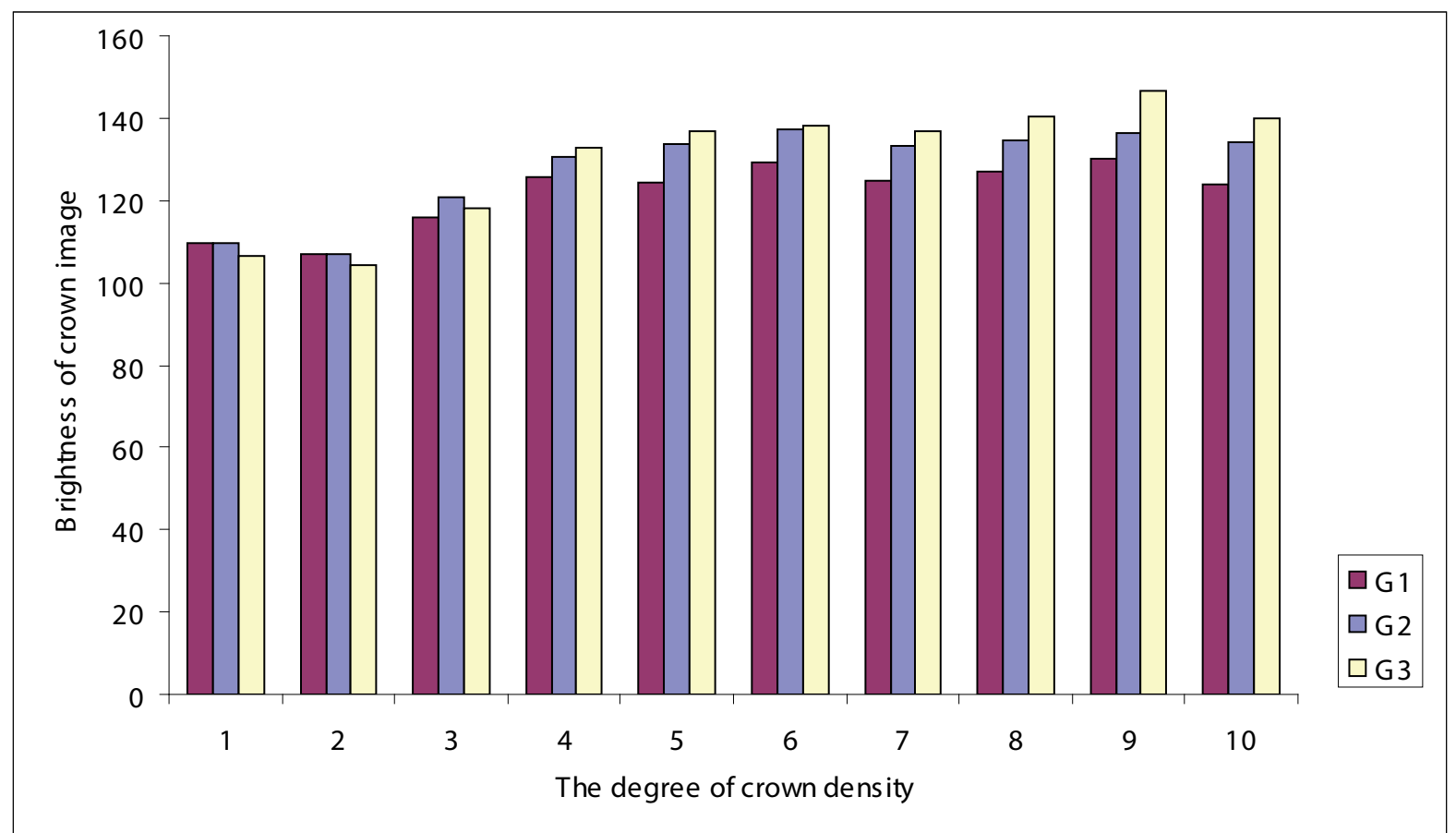

Figure 6. The brightness of crowns in green channel UAV according to degrees of crown density for 3 variants $(1,2$ and 3$)$ 


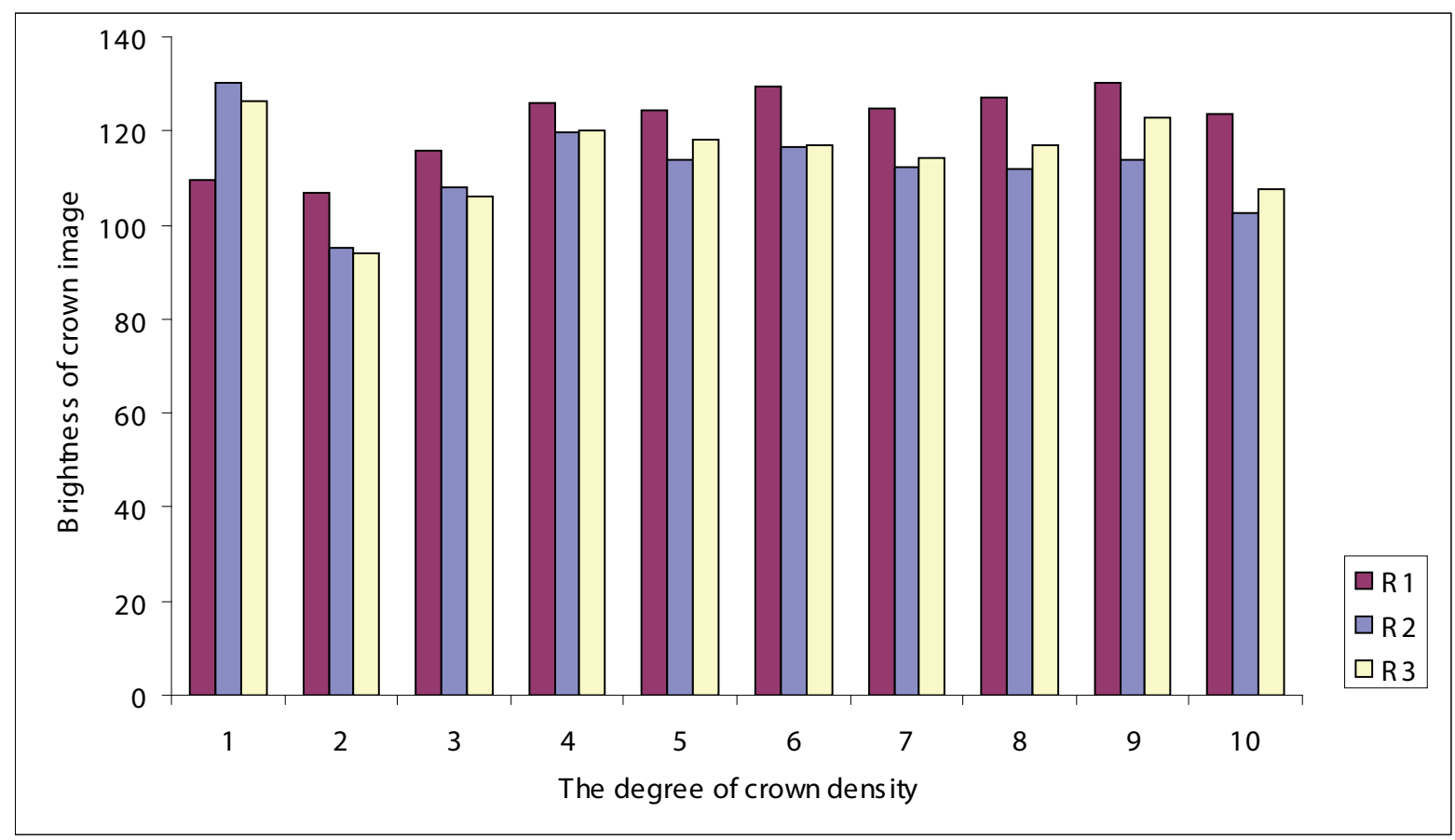

Figure 7. The brightness of crowns in red channel UAV according to degrees of crown density for 3 variants $(1,2$ and 3$)$

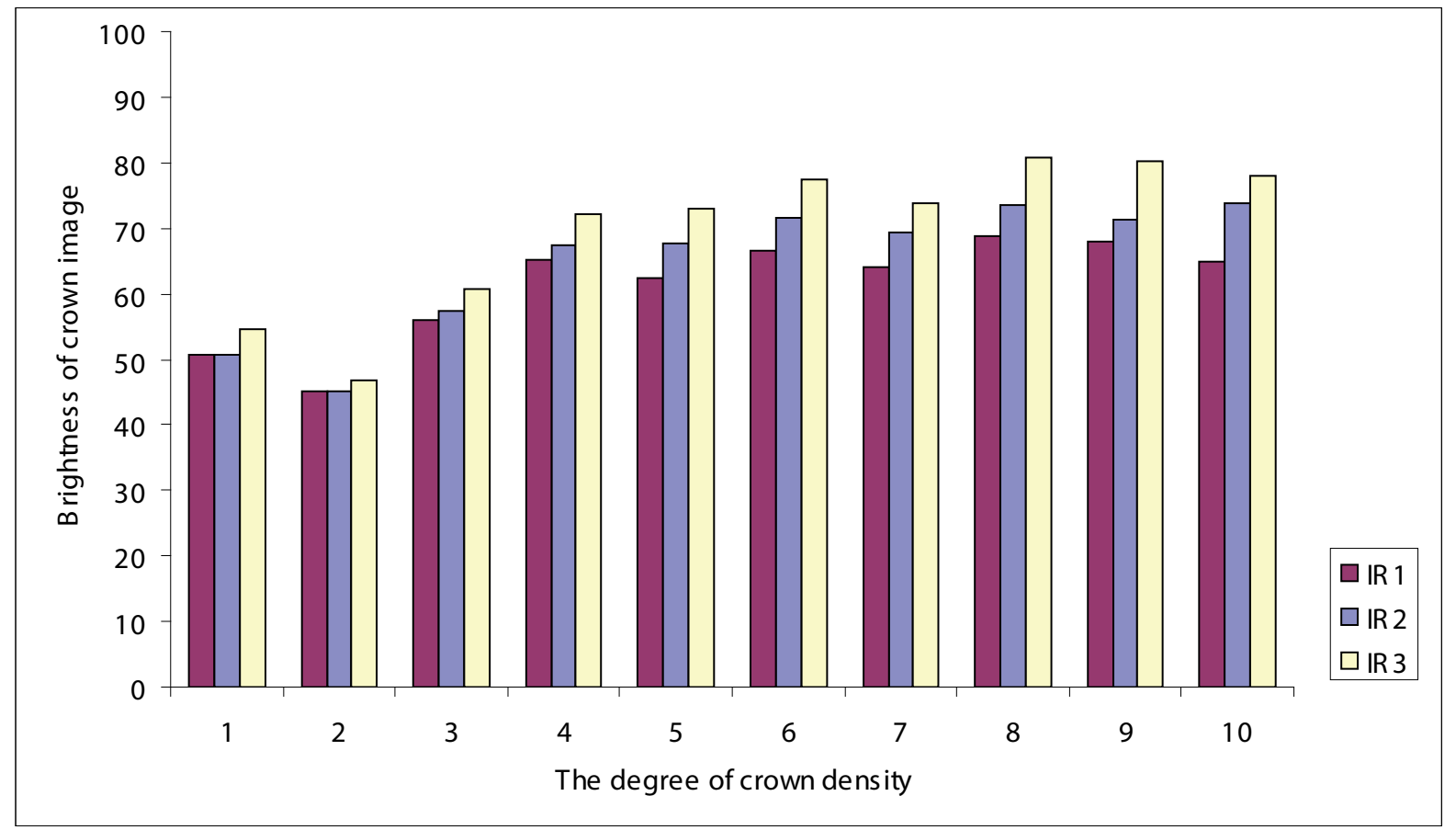

Figure 8 . The brightness of crowns in near infrared channel UAV according to degrees of crown density for 3 variants $(1,2$ and 3) 


\section{Discussion}

The presented studies proved that crowns belonging to different density classes vary significantly in terms of the mean pixel brightness. In particular, this applies to the class of trees with a very high degree of defoliation and dead trees. It should be noted that attempts were made to perform analyses for classes relatively close to each other, differing in their degree of crown density by only $10 \%$.

Given the clarity of graphs of tree crowns in different spectral channels and variants (Figs. 5-8), it seems that the field classification was carried out correctly. Spectral values analysis, recorded in each channel, indicates a high degree of similarity between the variants of crowns. For all variants trend are very similar and with the increase of needles' volume, the reflection also increases. Mean brightness values of the whole crowns (variant 1) differ significantly from the other variants in all spectral channels. Variant 2 and 3 are very similar in channel 2 and 3. When basic statistics have been compared, it was clear that these differences are very small (Table 2) and it is hard to detect which variant gives best results in classification of trees densities. On the other hand, this may lead to the conclusion that if during the automatic segmentation at least part of the crown is detected, it will not influence significantly the accuracy of density analysis. The most promising for classification are green and infrared spectral ranges, in which differences between classes are the highest. Other author findings are that crown density was well correlated with the slope of the narrow red-edge (Coops et al. 2004). Red edge was not available with Sigma camera.

It is hard to explain why bars shown on images 5-8 for defoliation classes 1 and 2 have the opposite trend. The values for class 1 are greater than for class 2 . This may be due to the fact, that class 1 represent trees having such small volume of needles, that most of the recorded information come from underneath the vegetation canopy. For class 2 more needles were present on the trees, but with these classes spectral reflection from branches and ground/understory dominated, and curves have a rising trend (Spanner et al. 1990; Stone \& Haywood 2006). From class 5 growth curve is barely visible and on the end (class 9 or 10) going down. This can be interpreted as a saturation of the horizontal crown projection with needles. Additional needles, hidden under located above, can be seen for observatory in the field (3D observation), but no longer contribute significantly to the increase of the registered radiation reflection (2D observation).

In this study Sigma camera was used, which have CCD sensor with low sensitivity to NIR wavelengths (Zmarz 2011). This camera characteristics cause low digital number $\mathrm{DN}$ values recorded above vegetation, which is rather unusual in NIR spectral range. Nevertheless, there is a clear difference in DN between crown variants (Fig. 8).
For variant 3 - registered reflectance was the highest, for variant 1 - the lowest. It can be interpreted that from variant 3 to 1 more background and les leaf reflection was recorded. It is obvious, because from variant 3 to 1 more outer parts of crowns were analyzed.

Future works regarding the described topic will be related to the analyses of the understory vegetation and development of efficient method of single tree segmentation.

\section{Acknowledgement}

The study was based on images acquired in the frame of the internal project titled "Assessment of the pine stands health on the basis of non-metric multispectral digital images obtained with an unmanned aerial vehicle", performed in 2011 at the Faculty of Forestry, Warsaw University of Life Sciences.

\section{References}

AFL, 2003, Luftbildinterpretationsschlüssel - Bestimmungsschlüssel für die Beschreibung von strukturreichen Waldbeständen im Color-Infrarot-Luftbild. Landesforstpräsidium Sachsen, Schriftenreihe 26.

Beker C., 1993, Ocena defoliacji drzew jako podstawowe kryterium klasyfikacji stanu zdrowotnego lasu [Rating defoliation of trees as the basic criterion for the classification of forest health], Prace IBL seria B 18: 89-94.

Będkowski K. \& Stereńczak K., 2012, Rozpoznawanie dębu czerwonego (Quercus rubra L.) na zdjęciach lotniczych wykonanych w końcowej fazie sezonu wegetacyjnego [Recognition of red oak (Quercus Rubra L.) on aerial photographs taken in the final stage of the growing season], Studia i Materiały Centrum Edukacji Przyrodniczo-Leśnej, R. 14, z. 4 (33): 168-177.

Borecki T., 1991, Ocena stanu zdrowotnego lasu (LZD Rogów, część Nadl. Wyszków) na podstawie stałych powierzchni próbnych [Assessment of forest health (LZD Rogow, part of Wyszkow Forest District) on the basis of permanent sample plots], [in:] Methods for assessing the condition and changes in forest resources, Wydawnictwo SGGW-AR, Warszawa: 119-130.

Borecki T. \& Keczyński A., 1992, Atlas ubytku aparatu asymilacyjnego drzew leśnych [Atlas of foliage losses by forest trees]. Agencja Atut, Warszawa.

Bychawski W., Iracka M. \& Zawiła-Niedźwiecki T., 1984, Metodyka określania zdrowotnego i sanitarnego stanu lasu na podstawie spektrostrefowych zdjęć lotniczych. Opis technologiczny [The methodology for determining forest health and condition based on aerial CIR photographs. Description of technology], Instytut Ge- 
odezji i Kartografii. Ośrodek Przetwarzania Obrazów Lotniczych i Satelitarnych, Warszawa.

Coops N. C., Stone C., Culvenor D. S. \& Chisholm L., 2004, Plant and Environment Interactions - Assessment of Crown Condition in Eucalypt Vegetation by Remotely Sensed Optical Indices, Journal of Environmental Quality 33: 956-964.

Dmyterko E., 1996, Metodyka określania stopnia uszkodzenia drzewostanów sosnowych przez imisje przemysłowe [A method for identification of the level of pine stand damage caused by industrial immisions], Prace IBL, ser. A 782: 127-155.

Fibich F., Zirm K., Holzwieser M., Mannsberger G., Schamann M., Eber G., Kirmes A. \& Knappitsch E., 1986a, Erhebung der Vitalität der Vegetation im Gemeindegebiet von Mödling. Teil 1. Vitalität des Waldes. Österreichisches Bundesinstitut für Gesundheitswesen, Wien.

Greer J. D., Hoppus M. L. \& Lachowski H. M., 1990, Color infrared photography for resource managementunique attributes improve vegetation mapping and resource management, Journal of Forestry 88 (7): 12-17.

Heidingsfeld N., 1993, Neue Konzepte zum Luftbildeinsatz für großräumig permanente Waldzustandserhebungen und zur bestandesbezogenen Kartierung flächenhafter Waldschäden. Mitteilungen aus der Forstlichen Versuchsanstalt Rheinland-Pfalz, 23/93.

Hildebrandt G. \& Gross C. P., 1992, Erfassung von Waldschäden in Luftbildern - Praxis und künftige Entwicklung, Der Wald, 42. Jg., 3: 76-79.

Idrisi 2009, Idrisi Taiga Manual, Clark Labs, Worcester, USA.

Jaszczak R., 2000, Charakterystyka wskaźników uszkodzenia koron drzew sosny zwyczajnej (Pinus sylvestris L.) różnych klas biosocjalnych [Description of tree crown damage indices in scots pine (Pinus Sylvestris L.) of different biosocial classes], Sylwan 144 (9): 65-76.

Jaszczak R., 2001, Zmiana defoliacji koron i przemieszczanie się drzew sosny zwyczajnej (Pinus sylvestris L.) między stopniami przerzedzenia [Change of crown defoliation and tree relocation of scots pine (Pinus Sylvestris L.) between degree of stand density reduction], Sylwan 145 (2): 15-26.

Kenneweg H., 1989, Remote sensing approaches to assessment and diagnosis of forest decline, [in:] Air Pollution and Forest Decline (J.B. Bucher \& I. Bucher-Wallin (eds.). Proc. 14th Int. Meeting for Specialists in Air Pollution Effects on Forest Ecosystems, IUFRO P2.05, Interlaken, Switzerland, Oct. 2-8, 1988. Birmensdorf: 217-221.

Miścicki S., 1981, Zależność miedzy przyrostem miąższości a barwą korony sosny na lotniczych zdjęciach spektrostrefowych $\mathrm{z}$ rejonu słabych uszkodzeń przemysłowych drzewostanów [Relationship between volume increment and color of pine crowns on air spectro-zonal photos from the region of weak industrial damage in forests stands], Sylwan 5: 9-19.

Mozgawa J., Olenderek H., Piekarski E., Borecki T., Będkowski K., Korpetta D., Kamińska G. \& Karaszkiewicz W., 1994, Interpretacja uszkodzeń drzewostanów na lotniczych obrazach wideo [Interpretation of the stand damages at airborne video images]. Fundacja Rozwój SGGW, Warszawa.

Pillmann W. \& Zobl Z., 1988, Erarbeitung spektraler Signaturen zur Scannerbildverarbeitung - Projektstufe IV: Verarbeitung von Scannerdaten für Zwecke der Waldzustandserkennung im Wienerwald. Österreichisches Bundesinstitut für Gesundheitswesen.

Pinz A., 1988, Ein bildverstehendes Expertensystem zur Erkennung von Bäumen auf Farb-Infrarot-Luftbildern. Dissertation, Technisch Naturwissenschaftliche Fakultät, Technische Universität Wien.

Pollanschütz J., 1968, Erste Ergebnisse über die Verwendung eines Infrarot-Farbfilmes in Österreich für die Zwecke der Rauchschadensfeststellung. Centralblatt für das gesamte Forstwesen, 85 Jhg., Heft 2, Seite 65-79.

Pollanschütz J., 1981, Grossräumige Immissionszonenkartierung in Steiermark und Tirol mit Falschfarbenluftbildern. Mitteilungen der Forstlichen Bundesversuchsanstalt Wien 135: 125-133.

PPGiK 1984, Metodyka oceny szkód w drzewostanach z wielospektralnych zdjęć lotniczych [The methodology of assessing damage in stands based on multispectral aerial photographs]. Państwowe Przedsiebiorstwo Geodezji i Kartografii w Pradze, Ośrodek Zdalnego Badania Ziemi, Praga.

Rango A. \& Laliberte A. S., 2010, Impact of flight regulations on effective use of unmanned aircraft systems for natural resources applications, Journal of Applied Remote Sensing, Vol. 4, 13 p. http://jornada.nmsu.edu/ bibliography/10-021.pdf

Redfern D. B. \& Boswell R. C., 2004, Assessment of crown condition in forest trees: comparison of methods, sources of variation and observer bias, Forest Ecology and Management 188: 149-160.

Schneider W. \& Plank H., 1981, Digitale Verarbeitung von Farb-Infrarot-Luftbildern. Bisherige Erfahrungen mit dem Bildabtaster "Optronics". Mitteilungen der Forstlichen Bundesversuchsanstalt Wien 135: 113-123.

Schneider W., 1989, Verfahren, Möglichkeiten und Grenzen der Fernerkundung für die Inventur des Waldzustandes. FBVA Berichte, Sonderheft. Schriftenreihe der Forstlichen Bundesversuchsanstalt, Wien.

Stone Ch. \& Haywood A., 2006, Assessing canopy health of native eucalypt forests, Ecological Management \& Restoration 7: 24-30.

Socha J. \& Ochał W., 2002, Tendencja wzrostowa wierzchołka i stopień defoliacji koron drzew w drzewosta- 
nach sosnowych wzrastających w wybranych regionach przemysłowych Polski południowej [Apex growth trends and crown defoliation in pine stands growing in the selected industrial regions of southern Poland], Sylwan 146 (5): 53-60.

Spanner M. A., Pierce L. L., Peterson D. L. \& Running S. W., 1990, Remote sensing of temperate coniferous forest leaf area index, The influence of canopy closure, understory vegetation and background reflectance, International Journal of Remote Sensing, 11: 95-111.

Stereńczak K., \& Będkowski K., 2012, Ocena stanu zdrowotnego drzewostanów sosnowych na podstawie niemetrycznych wielospektralnych zdjęć cyfrowych uzyskanych za pomocą bezzałogowego statku latającego [Assessment of the scots pine stands health based on non-metric multispectral digital images obtained by unmanned aerial vehicle]. Raport końcowy projektu 50510-03260052, SGGW w Warszawie, Katedra Urzadzania Lasu, Geomatyki i Ekonomiki Leśnictwa.

Suzuki T., Amano Y., Hashizume, Suzuki S. \& Yamaba A., 2010, Generation of Large Mosaic Images for Vegetation Monitoring Using a Small Unmanned Aerial Vehicle, Journal of Robotics and Mechatronics 22 (2): 212-213.

Taxus, 2010, Taxus SI Sp. z o.o. Samolot do fotografii $\mathrm{z}$ powietrza [An airplane for aerial photography. Technical Data], Warszawa.

Wastenson L., Alm G., Kleman J. \& Wastenson B., 1987, Swedish experiences on forest damage inventory by remote sensing methods. The Int. Journal of Aerial And Space Imaging, Remote Sensing and Integrated Geographical Systems 1 (1): 43-52.

Wójcik R., 2000, Analiza zmian ilościowych aparatu asymilacyjnego w drzewostanach sosnowych Nadleśnictwa Wyszków [Analysis of quantitative changes in fo- liage in pine stands of the Wyszków Forest District], Sylwan 144 (8): 39-46.

Wójcik R. \& Czarnecka R., 2001. Cechy morfologiczne korony jako wskaźnik uszkodzenia drzewostanów sosnowych [Morphological traits of crown as indicators of damage of pine stands], Sylwan 145 (4): 79-88.

Zawiła-Niedźwiecki T. \& Fedorowicz-Jackowski W., 1993, Forest monitoring of Karkonosze and Tatra Mountains in Poland with the use of GIS technology and ground, cartographic and remotely sensed data. Proc. of the MAB/IUCN Conference on "Mountain National Parks and Biosphere Reserves: Monitoring and Management" held in Czech Krkonose National Park, 20-23 September: 11 .

Zirm K., Fibich F., Hackl J., Malin H., Mauser H., Weinwurm M., Eber G. \& Malin J., 1985a: Erhebung der Vitalität des Waldes in Vorarlberg. Erste Untersuchungsergebnisse. Österreichisches Bundesinstitut für Gesundheitswesen, Wien.

Zmarz A., 2011, Zastosowanie bezzałogowych statków latających do pozyskania danych obrazowych o lesie [Applying unmanned aerial vehicles for obtaining forests' image data]. Dep. of Forest Management, Geomatics and Economics, Warsaw University of Life Sciences - SGGW, Warsaw (PhD thesis).

Zmarz A., Będkowski K., Miścicki S. \& Plutecki W., 2012, Ocena stanu zdrowotnego świerka na podstawie analizy zdjęć wielospektralnych wykonanych fotograficznymi aparatami cyfrowymi przenoszonymi przez bezzałogowy statek latający [Assesment of norway spruce health using multispectral images acquired from unmanned aerial vehicle with non-metric cameras]. Archiwum Fotogrametrii, Kartografii i Teledetekcji 23: $541-550$. 
